\title{
A Possibility of Functioning Biogas Plant at a Poultry Farm
}

\author{
Damian Janczak', Jakub Mazurkiewicz² ${ }^{*}$, Wojciech Czekała', Magdalena Myszura², \\ Kamil Kozłowski ${ }^{1}$, Aleksandra Jeżowska ${ }^{1}$ \\ 1 Institute of Biosystems Engineering, Poznań University of Life Sciences, ul. Wojska Polskiego 50, 60-627 \\ Poznań, Poland \\ 2 Institute of Soil Science and Environment Shaping, University of Life Sciences in Lublin, ul. St. Leszczyńskiego 7, \\ 20-069 Lublin, 20-950 Lublin, Poland \\ * Corresponding author's e-mail: jakub.mazurkiewicz@up.poznan.pl
}

\begin{abstract}
The biogas production constitutes one of renewable energy sources (RES) . In addition, wastes are preferred for energy production. In the case of some wastes, e.g. poultry manure, it is difficult to conduct anaerobic digestion in monofermentation. The aim of this work was to plan the biogas plant, in which the main substrate is the waste from a poultry farm. The scope of work included: preparation of a biogas plant technological project, determining the amount of biogas and methane that can be produced annually on the example of the selected poultry farm, performing the energy and financial calculations for the current conditions prevailing on the renewable energy market in Poland. The installation project assumed the location of a biogas plant at an existing poultry farm - the source of the substrate. The micro-biogas plant includes a fermentation tank with a capacity of $500 \mathrm{~m}^{3}$ and storage of digestate pulp with a capacity of $700 \mathrm{~m}^{3}$. The assumed power biogas plant will generate $112 \mathrm{~kW}$ of electricity and $120 \mathrm{~kW}$ of heat. The installation will operate in a single-stage mesophilic technology $\left(39^{\circ} \mathrm{C}\right)$, which will avoid incurring additional costs related to heating and the construction of additional fermentation tanks. The use of poultry manure by anaerobic digestion provides benefits through biogas technology. It is necessary to examine the technology in terms of biogas production, which is carried out under better sanitary and environmental conditions. This work was undertaken to investigate the environmentally friendly removal of poultry manure through biogas technology to obtain the best economic effect, and employ it further, e.g. as a fertilizer.
\end{abstract}

Keywords: poultry waste, biogas, renewable energy, environmental protection, sustainable development, animal production

\section{INTRODUCTION}

Poultry farms are becoming increasingly popular worldwide due to the relatively cheap and fast meat production. However, such a large production is directly related to the amount of waste (e.g. manure) that requires proper management (Chaump et al. 2018, Çoban et al. 2016, Anaswara 2015, Wang et al. 2014).

One of the possibilities is to use the manure as a fertilizer (Czekała et al. 2015). There are different types of poultry manure, e.g. high rise manure, cage manure, broiler manure and deep litter manure (Amanullah et al. 2010). Regardless of the type, such an organic waste contains various amounts of water, mineral nutrients, organic matter (Duan et al. 2018).

The application of such an organic fertilizer improves the physical condition of the soil, increasing the soil porosity and reducing the bulk density, which allows for smooth root penetration and growth in the soil (Czekała et al. 2019). A chemical fertilizer, used together with organic fertilizer, supports the plant growth and contributes to higher productivity (Wolna-Maruwka et al. 2015). Among the various organic fertilizers, poultry manure helps to improve the condition of the soil, increase the water retention capacity in the soil and provide. 
Poultry manure can provide all 13 types of soil micronutrients in a significant amount that inorganic fertilizer cannot (Subedi et al. 2018). The above-mentioned waste from poultry farms is rich in: nitrogen, phosphorous, iron, potassium, calcium, magnesium, sulphur, copper, manganese, zinc, molybdenum, chlorine, boron. However, the content of these components varies, depending on the moisture content and age of the manure, as well as on the age of the poultry (Amanullah et al. 2010, Nahm 2007).

The poultry manure may exhibit highly variable nutrient characteristic, depending on their processing conditions. The litter to manure ratio and the moisture content are among the factors causing the greatest variation in manures from different houses. The poultry manure is composed of ca. 3-5\% nitrogen, $1.5-3 \%$ phosphorous and $1.5-3.0 \%$ potassium as well as significant amounts of micro-nutrients (Amanullah et al. 2010).

Direct soil spreading of the poultry manure for crop fertilization is a traditional and still the most applied method. However, the contemporary rearing poultry methods have made the issue more complicated. The majority of poultry manufactured these days is litter-free. Litter is not used in the case of birds bred in cages or slots (Duan et al. 2018, Amanullah et al. 2010).

The litter used in manure absorbs moisture and facilitates keeping the manure friable, resulting in the atmospheric exposure of a large surface. In turn, the manure without litter contains $60-70 \%$ moisture, complicating the application process. Meanwhile, in the event of storage aimed at reducing the moisture content, nutrient losses appear and the process is less cost-effective (Amanullah et al. 2010, Duan et al. 2018). Another issue pertaining to this type of manure is the very quick release of $\mathrm{N}$, so in the event of negligence in its application, burning may occur.

The poultry manure handling, storage and direct application involve numerous problems including the emission of ammonia, nitrate pollution, contamination of surface and underground water, attracting and breeding flies as well as public nuisance (Amanullah et al. 2010, Harremoes 1991).In order to apply the manure quickly and prevent nutrient loss and environmental pollution, it can be used as follows: soil fertilization for crops, activator for button mushroom cultivation, feed for fish and livestock, energy generation biogas, electricity (Amanullah et al. 2010).
Another option for managing the manure is to use it for energy production. The availability of sufficient, inexpensive and environmentallyfriendly energy is one of the greatest challenges in the world (Çoban et al. 2016, Miah et al. 2016). Renewable energy sources are of interest to the world due to the climate change and unavoidable depletion of limited resources, such as coal and oil (Arshad et al. 2018, Kian Heng 2017).

The biogas is an environmentally friendly and one of the most efficient and effective renewable energy options. The biogas can be produced using the chicken manure, although it is not easy due to the very high nitrogen content of the droppings (Duan et al. 2018, Miah et al. 2016). The biogas is produced in the fermentation process; fermentation digestate sludge is rich in essential nutrients that can be used as a very good fertilizer (Czekała et al. 2017). The anaerobic digestion is a process of organic materials degradation by microorganisms without oxygen. It is a multi-stage biological process in which organic carbon is mainly converted to carbon dioxide and methane (Miah et al. 2016).

The biogas production by anaerobic digestion is considered an attractive and efficient technology for processing animal waste (Bayrakdar et al. 2017), with the exception of the main objective - removal of matter and control of environmental pollution, while producing the biogas for the needs of local energy. The poultry manure with an original dry matter of $20-25 \%$ or more has a high content biodegradable organic matter. Therefore, the conversion of this organic matter to renewable energy in the anaerobic digestion process will not only reduce the negative impact on the environment, but will also significantly contribute to the energy supply (Duan et al. 2018, Anaswara 2015).

Although the technology of methane fermentation in the processing of animal manure for biogas production is very mature and intensive research has been intensively carried out, limited studies can be found on anaerobic digestion of poultry manure, especially mono-digestion (Chaump et al. 2018).

The process of poultry manure fermentation, with a low carbon/nitrogen $(\mathrm{C} / \mathrm{N})$ ratio of $5-10$, usually ends with reactor instability or even failure due to its inactive enzymes that affect the material transport and inhibit methanogenic microflora as a result of ammonia accumulation (Duan et al. 2018, Lewicki et al. 2016, Wang et 
al. 2014, Pokój 2014). Several attempts have been proposed to avoid the accumulation of ammonia during that process. Co-fermentation with various carbon-rich types of biomass was studied to obtain a favorable $\mathrm{C} / \mathrm{N}$ ratio, such as with pork waste, municipal solid waste and other biowaste, in particular the biomass from agricultural production (Chaump et al. 2018, Duan et al. 2018, Brown and Li 2013).

The amount of waste from the agro-food industry and poultry manure in Poland is still increasing in parallel. One of the most advantageous solutions of processing these wastes together is anaerobic co-digestion (Çoban et al. 2016, Kian Heng 2017, Amanullah et al. 2010, Çoban et al. 2016, Sądej et al. 2016, Pokój 2014.

At present, there are 96 agricultural biogas installations in Poland (AMA 2018); with total power about $100 \mathrm{MW}$, but the potential of the biogas market from bio-waste, according to our estimates is 3000-4500 MW. Poland is the leader in poultry production in Europe (nearly 1 billion a year). Currently, the poultry waste is processed into mink feed. When the mink farms are closed, there will be a great problem with waste management. 80-100 million $\mathrm{Mg}$ of animal waste per year are created in Poland; for comparison: in India 12.1 million Mg (Amanullah et al. 2010), in Iran ca. 2 million $\mathrm{Mg}$ (Çoban et al. 2016). The stored droppings generate $0.3-0.5$ million $\mathrm{Mg} \mathrm{CH}$ per year. The storage of the waste from poultry farms is an increasing environmental and social problem (e.g. strong odor emissions) in Poland and similar problems are encountered in other countries too (Çoban et al. 2016, Kian Heng 2017, Amanullah et al. 2010). The aim of this work was to plan a biogas plant, in which the main substrate is the waste from poultry farms.

\section{MATERIALS AND METHODS}

The study examined the biogas yield of the following substrates: chicken manure, postslaughter waste, barley straw and grass silage. All materials came from two poultry farms located in the West Pomeranian Voivodeship.

The samples collected for testing were stored under refrigeration conditions at $4^{\circ} \mathrm{C}$ until the start of the experiment. The research on the anaerobic digestion process was carried out at the university laboratory based on the commonly used German standards DIN 38 414/S8 and VDI 4630. The biogas efficiency tests were conducted in reactors with a capacity of $2 \mathrm{dm}^{3}$ placed in a water bath at a temperature of $39( \pm 1)^{\circ} \mathrm{C}$ (Fig. 2).

The scope of work included:

- determining the amount of biogas and methane that can be produced annually on the example of the selected poultry farm,

- preparation of a biogas plant technological project,

- performing the energy and financial calculations for the current conditions prevailing on the renewable energy market in Poland.

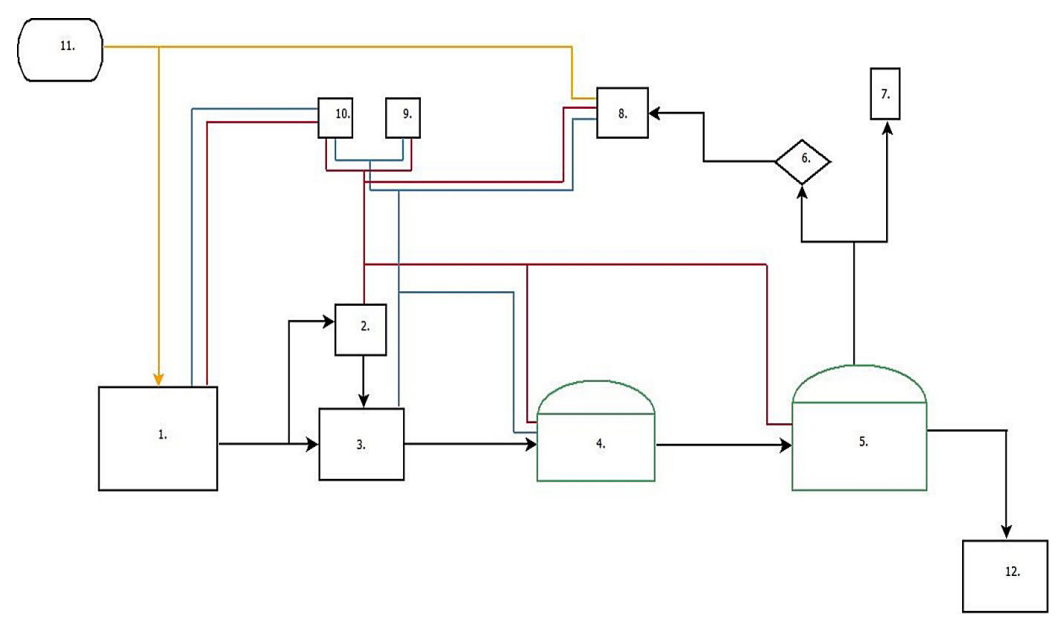

Fig. 1. Diagram of the planed biogas plant

1 - Poultry farm, 2 - Substrate hygienization, 3 - Substrate warehouse, 4 - Anaereobic digestion tank, 5 - Postfermentation pulp tank, 6 - Biogas desulphurisation station, 7 - Torch, 8 - CHP unit, 9 - Emergency cooling, 10 - Heat exchanger, 11 - Energy network, 12 - Organic fertilization of cultivated areas 


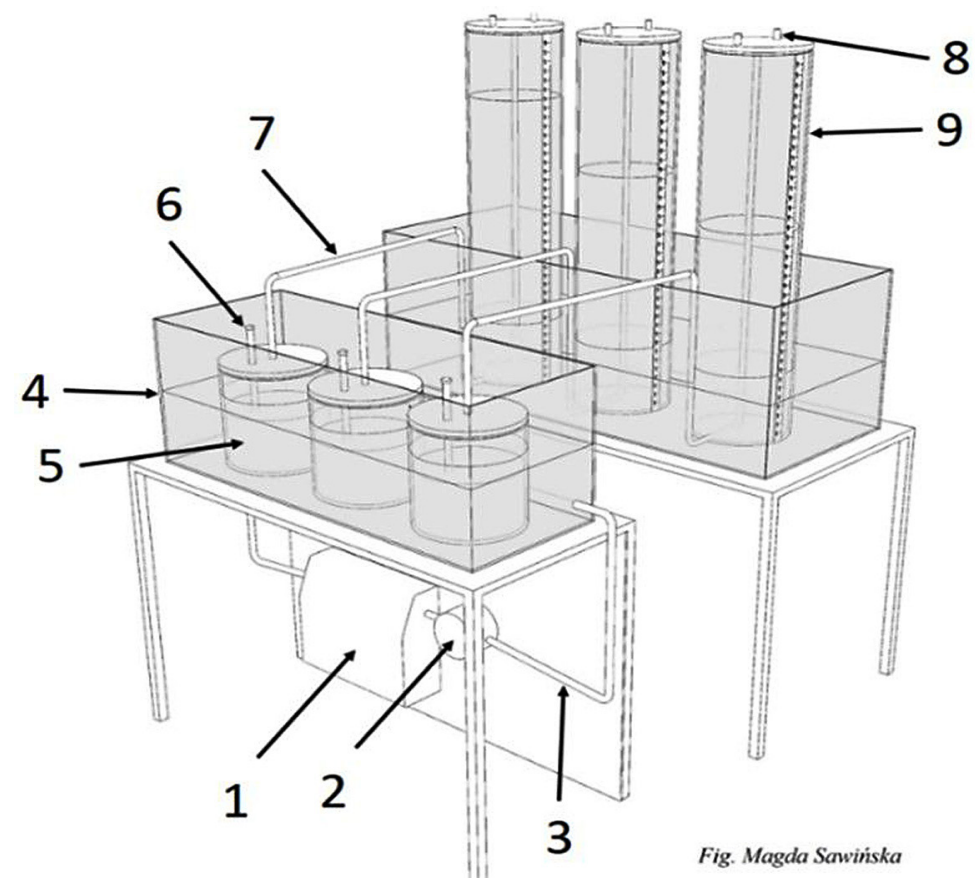

Fig. 2. Scheme of biofermenter for biogas production research (3-chamber section)

1 - water heater with temperature regulator, 2 - water pump, 3 - insulated conductors of calefaction liquid, 4 - water coat, 5 - biofermenter with charge capacity $2 \mathrm{dm}^{3}, 6$ - sampling tubes, 7 - biogas transporting tube, 8 - gas sampling valve, 9 - biogas volume-scale reservoir (Cieślik et al. 2016)

The installation project assumed the location of a biogas plant at an existing poultry farm, the source of the substrate. The owner has a second farm in another location, about $5 \mathrm{~km}$ away, from which the waste will be regularly collected and transported to the biogas plant. The location of the installation close to the plant reduces the transport costs.

The main research tasks - qualitative and quantitative analysis of the gases produced $\left(\mathrm{CH}_{4}\right.$, $\mathrm{CO}_{2}, \mathrm{NH}_{3}, \mathrm{O}_{2}, \mathrm{H}_{2} \mathrm{~S}$ ) was carried out daily using Geotech GA5000 gas analyzer.

\section{Financial and energy calculation methodology}

In order to determine the potential energy potential and calculate the revenue resulting from the production of electricity and heat, mathematic formulas described by Kozlowski were used (Kozłowski et al. 2017).

\section{RESULTS}

Due to the high nitrogen content in chicken manure, the best way to obtain a more proper $\mathrm{C}: \mathrm{N}$ ratio for effective fermentation purposes the co-fermentation is necessary. As additional substrates, post-slaughter waste, straw and silage from grasses will be used. In the table below (Table 1), the available substrates and their characteristics were presented together with the biogas efficiency and methane content.

On the basis of the biogas yields of the supplied substrates and their annual deliveries, basic energy parameters were calculated (Table 1-3).

The production capacity of biogas produced as a result of methane fermentation of the chicken manure was about $188 \mathrm{~m}^{3} \cdot \mathrm{Mg}^{-1}$ (fresh mass), with an average methane content of about $56 \%$.

With a quantity of the above-mentioned available annual supplies of substrate quantities, the volumes of fermentation tank with a capacity

Table 1. Available substrates and their characteristics

\begin{tabular}{|c|c|c|c|}
\hline Substrate & Mass of substrate $\left(\mathrm{Mg} \cdot \mathrm{year}{ }^{-1}\right)$ & Biogas efficiency $\left(\mathrm{m}^{3} \cdot \mathrm{Mg}^{-1}\right)$ & Methane content $(\%)$ \\
\hline Chicken manure & 1620.00 & 188.53 & 56.00 \\
\hline Post-slaughter waste & 25.80 & 245.21 & 70.00 \\
\hline Barley straw & 76.80 & 442.54 & 52.00 \\
\hline Grass silage & 396.00 & 224.61 & 55.00 \\
\hline
\end{tabular}


Table 2. Energetic potential of the substrates

\begin{tabular}{|l|c|c|}
\hline \multicolumn{1}{|c|}{ Parameters } & Value & Unit \\
\hline Hydraulic retention time & 86 & day \\
\hline Dry mass of the mixture & 44 & $\%$ \\
\hline The capacity of the methane fermentation tank & $502.79 \approx 500$ & $\mathrm{~m}^{3}$ \\
\hline The capacity of the digestate storage tank & $690 \mathrm{~m}^{3} \approx 700$ & $\mathrm{~m}^{3}$ \\
\hline The weight of the used substrate & 2118 & $\mathrm{Mg}^{3}$ year \\
\hline
\end{tabular}

Table 3. Energetic (electrical and thermal) potential of the substrates

\begin{tabular}{|l|c|c|}
\hline \multicolumn{1}{|c|}{ Parameters } & Value & Unit \\
\hline The volume of produced biogas & 434677 & $\mathrm{~m}^{3}$ \\
\hline The volume of methane produced & 242054 & $\mathrm{~m}^{3}$ \\
\hline The amount of electricity produced & 965 & $\mathrm{MWh}^{\prime} \cdot \mathrm{yr}^{-1}$ \\
\hline The amount of heat produced & 1037 & $\mathrm{MWh}^{-} \mathrm{year}^{-1}$ \\
\hline The amount of heat produced & 3786 & $\mathrm{GJ}^{-} \mathrm{year}^{-1}$ \\
\hline Electrical power of the installation & 112 & $\mathrm{~kW}$ \\
\hline Thermal power & 120 & $\mathrm{~kW}$ \\
\hline
\end{tabular}

of $500 \mathrm{~m}^{3}$ and a storage of digestate pulp with a capacity of $700 \mathrm{~m}^{3}$ ware calculated (Table 2). The nominal volumetric load of the fermentation tank was adopted as $4.5 \mathrm{~kg}$ of dry organic matter $\mathrm{m}^{-3} \cdot \mathrm{d}^{-1}$.

The amount of substrates available in a selected poultry farm allows for the production of $112 \mathrm{~kW}$ of electricity and $120 \mathrm{~kW}$ of heat.

Input data for calculation:

- coefficient of energy efficiency of methane $0.009968 \mathrm{MWh} \cdot \mathrm{m}^{-3}$,

- electrical efficiency of a cogeneration 0.40 [-],

- thermal efficiency of a cogeneration 0.43 [-],

- cogeneration unit operating time during the year $-8,600 \mathrm{~h}$.

The amount of electricity generated in the designed installation will be approx. $965 \mathrm{MWh} \cdot$ year $^{-1}$ and 1,037 MWh year $^{-1}$ heat (Table 3).

In order to properly calculate the profitability of the investment, which is the construction of an agricultural microbiogas plant, it is necessary to identify and calculate the costs of substrates, transport, exploitation, etc.

Input data for calculation:

- cost of technical service $-5 \%$ of investing cost

- cost of technical service $-7 \mathrm{PLN} \cdot \mathrm{MWh}^{-1}$

- min. 10 years amortization

- transport cost $-0.40 \mathrm{PLN} \cdot \mathrm{km}^{-1} \cdot \mathrm{Mg}^{-1}$

A list with outputs and the characteristics of individual costs are given in Table 4.

The operating costs will amount to approximately $288374 \mathrm{PLN} \cdot$ year $^{-1}$, and the revenue from the sale of electricity and heat approx.
$711020 \mathrm{PLN} \cdot$ year $^{-1}$. Such a balance of profits and losses will generate the income of approximately about 423646 PLN·year ${ }^{-1}$ (Table 5). Similar effects using the co-substrates from poultry farm and farm waste or by-products were used in other countries with very high poultry production $(\mathrm{Cu}-$ cui et al. 2018, Mia et al. 2016, Çoban et al. 2016, Anaswara 2015), even in a very large industrial scale (Kian Heng 2017).

\section{CONCLUSIONS}

The use of poultry manure by anaerobic digestion provides benefits through the biogas technology. It is necessary to examine the technology in terms of the biogas production, which is carried out under better sanitary and environmental conditions. This work was undertaken to investigate the environmentally friendly removal of poultry manure through biogas technology to obtain the

Table 4. Outputs and the characteristics of individual costs of the micro - biogas plant

\begin{tabular}{|l|c|}
\hline \multicolumn{1}{|c|}{ Costs } & Value (PLN) \\
\hline The cost of the substrate & 2618 \\
\hline The cost of the transport & 2618 \\
\hline The cost of technical service & 77000 \\
\hline The cost of technological service & 6755 \\
\hline The cost of the service & 83755 \\
\hline Depreciation cost & 154000 \\
\hline Staff cost & 48000 \\
\hline Exploitation cost & 288374 \\
\hline
\end{tabular}


Table 5. Economic balance of the biogas plant

\begin{tabular}{|l|c|c|}
\hline \multicolumn{1}{|c|}{ Financial data } & Value & Unit \\
\hline Price of electricity energy & 595 & PLN·MWh ${ }^{-1}$ \\
\hline Revenue from the sale of electricity & 579852 & PLN \\
\hline Price of thermal energy & 127 & PLN·MWh ${ }^{-1}$ \\
\hline Revenue from the sale of thermal energy & 132167 & PLN \\
\hline Total revenue & 712020 & PLN \\
\hline Profit & 423646 & PLN \\
\hline
\end{tabular}

best economic effect, and employ it further, e.g. as a fertilizer.

The implemented biogas plant project will reduce the costs associated with the disposal of problematic waste from a poultry farm, and the energy generated by the investor can be used to cover the farm energy demand or be sold to the local power grid.

From an economic and organizational point of view, the waste from a poultry farm, together with straw and silage from grass, are favorable substrates for agricultural biogas plants. The possibility of effective management of nuisance waste and neutralization of unpleasant odors are the advantages of the agricultural biogas plant based on co-substrates with poultry farm and farm by-products.

\section{Acknowledgements}

Publication supported by the Polish Ministry of Science and Higher Education as a part of the program of activities disseminating science from the project „Organization of the First International Science Conference - Ecological and Environmental Engineering”, 26-29 June 2018, Kraków.

\section{REFERENCES}

1. AMA. 2017. Register of agricultural biogas producers. Agricultural Market Agency. Current data as at 31.08.2017.

2. Amanullah, M., Sekar S., Muthukrishnan P. 2010. Prospects and Potential of Poultry Manure. Asian Journal of Plant Sciences, 9, 4, 172-182. doi:10.3923/ajps.2010.172.182

3. Anaswara, MG. 2015. Design and fabrication of low cost biogas digester using poultry waste and pig manure. International Research Journal of Engineering and Technology (IRJET), 2/4. https://www.irjet.net/ archives/V2/i4/Irjet-v2i4312.pd

4. Arshad, M., Bano, I., Shahzad, M., Younus, M., Abbas, M. 2018. Electricity generation from biogas of poultry waste: An assessment of potential and feasibility in Pakistan. Renewable and sustianable energry reviews, 81, 1241-1246. doi:10.1016/j. rser.2017.09.007.

5. Bayrakdar A., Molaey R., Sürmeli RÖ., Sahinkaya E., Çalli B. 2017. Biogas production from chicken manure: Co-digestion with spent poppy straw, International Biodeterioration \& Biodegradation, 119, 205-210. doi: 10.1016/j.ibiod.2016.10.058

6. Brown, D., Li, Y. 2013. Solid state anaerobic codigestion of yard waste and food waste for biogas production. Bioresource Technology, 127, 275-280. doi:10.1016/j.biortech.2012.09.081

7. Chaump, K., Preisser, M., Shanmugam, S., Prasad, R., Adhikari, S., Higgins, B. 2018. Leaching and anaerobic digestion of poultry litter for biogas production and nutrient transformation. Waste Management. doi:10.1016/j.wasman.2018.11.024.

8. Cieślik, M., Dach, J., Lewicki, A., Smurzyńska, A., Janczak, D., Pawlicka-Kaczorowska, J., Boniecki, P., Cyplik, P., Czekała, W. \& Jóźwiakowski, K. 2016. Methane fermentation of the maize straw silage under meso- and thermophilic conditions. Energy, 115/2, 1495-1502. doi:http://dx.doi.org/10.1016/j. energy.2016.06.070.

9. Çoban V., Çağman S., Eyidoğan M., Çanka Kılıç F., Kaya D. 2016. Economic Analysis of Biogas Production from Chicken Manure. 8th International Ege Energy Symposium and Exhibition - 2016.

10. ht t p :// a ka de mikpersonel. k o c a eli. edu.tr/volkan.coban/bildiri/volkan. coban17.01.2017_17.45.39bildiri.pdf

11. Czekała W., Dach J., Ludwiczak A., Przybylak A., Boniecki P., Koszela K., Zaborowicz M., Przybył K., Wojcieszak D., Witaszek K. 2015. The use of image analysis to investigate $\mathrm{C}: \mathrm{N}$ ratio in the mixture of chicken manure and straw. Proc. SPIE. 9631, Seventh International Conference on Digital Image Processing (ICDIP 2015), 963117. (July 06, 2015) doi: $10.1117 / 12.2197041$

12. Czekała W., Jeżowska A., Chełkowski D. 2019. The Use of Biochar for the Production of Organic Fertilizers. Journal of Ecological Engineering 20(1), 1-8. DOI: https://doi.org/10.12911/22998993/93869

13. Czekała W., Dach J., Lewicki A., Gajewska K., Staszak Ż. 2017. Utilization of digestate obtained 
from methane fermentation of chicken manure. IX International Scientific Symposium "Farm Machinery and Processes Management in Sustainable Agriculture", Lublin, Poland, 2017. DOI: 10.24326/ fmpmsa.2017.17

14. Cucui, G., Ionescu, C., Goldbach, I., Coman, M., Marin, E. 2018. Quantifying the Economic Effects of Biogas Installations for Organic Waste from Agro-Industrial Sector. Sustainability, 10/7. doi:10. 2582. 10.3390/su10072582.

15. Duan, N., Ran, X., Li, R., Kougias, P.G., Zhang, Y., Lin, C., Liu, H. 2018. Performance Evaluation of Mesophilic Anaerobic Digestion of Chicken Manure with Algal Digestate. Energies, 11/7, 1829. doi:10.3390/en11071829

16. Harremoes P. 1991. Danes nutrient battle depends on agricultural action. Water quality international, 3, 44-48.

17. Kian Heng L. 2017. Bio Gas Plant Green Energy From Poultry Wastes In Singapore. Energy Procedia, 143, 436-441. doi:10.1016/j.egypro.2017.12.708

18. Kozłowski, K.; Dach, J.; Lewicki, A.; Cieślik M.; Janczak, D.; Czekała W.; Mazurkiewicz J.; Sołowiej, P; Brzoski, M. 2017. Application Of Agri-Food Industry Waste To Biogas Production In Poland. Conference: 3rd Internacional Conference on Energy and Environment (ICEE) - Bringing Together Economics and Engineering Location: Porto, PORTUGAL Date: JUN 29-30, 2017. ICEE International Conference on Energy \& Environment, 603-608

19. Lewicki A., Kozłowski K., Pietrowski M., Zbytek Z. 2016. Methane fermentation of chicken droppings, Journal of Research and Applications in Agricultural Engineering, 61/4, 28-30

20. Miah M.R., Rahman, A.K.M.L., Akanda, M.R., Pulak, A., Rouf, M.A. 2015. Production of biogas from poultry litter mixed with the co-substrate cow dung. Journal of Taibah University for Science, 10, 497504. doi.org/10.1016/j.jtusci.2015.07.007

21. Nahm KH. 2007. Efficient phosphorus utilization in poultry feeding to lessen the environmental impact of excreta. World's Poultry Science Journal, 63/4, 625-654 doi.org/10.1017/S0043933907001663

22. Pokój T., Gusiatin ZM., Bułkowska K., Dubis B. 2014. Production of biogas using maize silage supplemented with residual glycerine from biodiesel manufacturing. Archives of Environmental Protection, 40/4, 17-29. doi: 10.2478/aep-2014-0035

23. Sądej W., Żołnowski AC, Marczuk O. 2016. Content of phenolic compounds in soils originating from two long-term fertilization experiments. Archives of Environmental Protection, 42/4, 104-113. doi: 10.1515/aep-2016-0047

24. Subedi, S., Srivastava, A., Sharma, MD., Shah, SC. 2018. Effect of organic and inorganic nutrient sources on growth, yield and quality of radish (Raphanus sativus L.) varieties in Chitwan, Nepal. SAARC Journal of Agriculture, 16/1, 61-69, doi:10.3329/sja. v16i1.37423.

25. Wang, X., Lu, X., Li, F., Yang, G. 2014. Effects of Temperature and Carbon-Nitrogen $(\mathrm{C} / \mathrm{N})$ Ratio on the Performance of Anaerobic Co-Digestion of Dairy Manure, Chicken Manure and Rice Straw: Focusing on Ammonia Inhibition. PloS ONE 9/5, e97265. doi:org/10.1371/journal.pone.0097265

26. Wolna-Maruwka A., Mocek-Płóciniak, A., Głuchowska, K., Schroeter-Zakrzewska, A., Borowiak, K., Niewiadomska, A., Starzyk, J., Dach, J. 2015. Assessment of the influence of composts on microbiological and biochemical parameters of substrates and the morphological traits of scarlet sage. Archives of Environmental Protection, 41(3)/3, 28-38. 